\title{
Geographic distributions, host plants and biology of species in the genus Huequenia (Coleoptera: Cerambycidae), with new records from Southwestern Argentina
}

\author{
Paola N. TuRienzo \& Osvaldo R. Di IORIO \\ Entomología, Departamento de Biodiversidad y Biología Experimental, Facultad de Ciencias Exactas y Naturales, $4^{\circ}$ Piso, \\ Pabellón II, (CP 1428) Ciudad Universitaria, Buenos Aires, Argentina; e-mail: paolaturienzo@yahoo.com
}

\begin{abstract}
Araucaria trees as host plants of the longhorned beetle Huequenia livida (Coleoptera: Cerambycidae) in Argentina are reviewed. Araucaria araucana is its natural host plant in SW Argentina, but the larvae also developed in dead branches of $A$. angustifolia and A. bidwillii (new host plant records), when both plants were kept in the same rearing cage with the natural host plant. Pinus contorta var. murrayana, also mentioned from Argentina, may be a recently adopted secondary host. A winter and a summer generation of $H$. livida was documented for the first time. Huequenia livida exceeds the actual natural distribution of $A$. araucana following the distribution of cultivated A. araucana and Pinus trees.
\end{abstract}

Key words: Araucaria araucana; stem borer; Huequenia; Achrysonini; South America.

\section{Introduction}

The longhorned beetle Compsa livida Germain, 1898 (Coleoptera: Cerambycidae) was described from Chile. Later it was transferred to the new genus Xenocompsa Martins, 1965 (Cerambycinae: Ibidionini) by Martins (1965), and again to the new genus Angolia Cerda, 1980 (Cerambycinae: Hesperophanini). A second species in this last genus was described (Angolia araucana Cerda, 1980). As Angolia Cerda, 1980 was preoccupied by Angolia Malloch, 1934 (Diptera), the new name Huequenia was proposed by Cerda (1986). Huequenia was transferred from Hesperophanini to Achrysonini (Cerambycinae) by Martins (2002), who mentioned both species only from Chile.

Until 2005, the genus Huequenia was not mentioned from Argentina (Di Iorio 2005). Turienzo (2005) published the first record for Huequenia livida (Coleoptera: Cerambycidae) from Argentina, together with the first known host plant from this country. Larval tunnels and pupal chambers of $H$. livida were described by Turienzo (2006). Villacide et al. (2005, 2006) also recorded $H$. livida from Argentina, but in a different host plant, and Gómez (2008) mentioned three species of Pinus as its host plants, without more details.

Araucaria trees are known as host plants of H. livida in Argentina. Some works have been made about extant Araucaria-insect associations, related to Araucaria angustifolia (Bertol.) Kuntze (Pastrana 1950; Mecke et al. 2000a,b, 2001, 2004a, b; Mecke \& Galileo 2004), Araucaria araucana (Molina) Koch (Hodge 1997; Turienzo 2005, 2006; Ferrer et al. 2007), Araucaria laubenfelsii Corbas (Mecke 2004b), Arau- caria muelleri (Carr.) Brong. et Griseb. (Mecke 2004b), Araucaria cunninghamii Aiton ex Don (Hawkeswood 1990, 1992), and Araucaria heterophylla (Salisb.) Franco (Hawkeswood 1992).

In this paper, a bibliographic review is presented, with corrections and new locality records for species in the genus Huequenia, together with emergence data from host plants. It is established here for the first time that $H$. livida is a bivoltine species with two generations per year, one large generation in autumn-winter, and a short one in summer.

\section{Material and methods}

Known localities and host plants of Huequenia sp. per locality are summarized in order to locate both in the composite map of the geographic distribution of the insect-host plant associations (Fig. 1).

Dead branches of Araucaria araucana with signs of infestation by Cerambycidae (Figs 2, 3, 5) were collected at three localities in Neuquén province, Argentina (Supplementary file: Table S1). These dead branches were located in old living trees cultivated inside public squares in urban areas (Figs 2,3), and they were infested with active larvae or emerging adults inside the pupal chambers. The branches were maintained in rearing cages made of mesh wire at ambient temperature to avoid interference with the natural conditions of emergences in the field.

Dead branches of Araucaria angustifolia and Araucaria bidwillii, obtained from cultivated trees in the province of Buenos Aires, were kept with $A$. araucana in the same rearing cages in laboratory (Buenos Aires, Ciudad Universitaria). After checking ovipositions in these additional branches, they were later transferred separately to rearing 


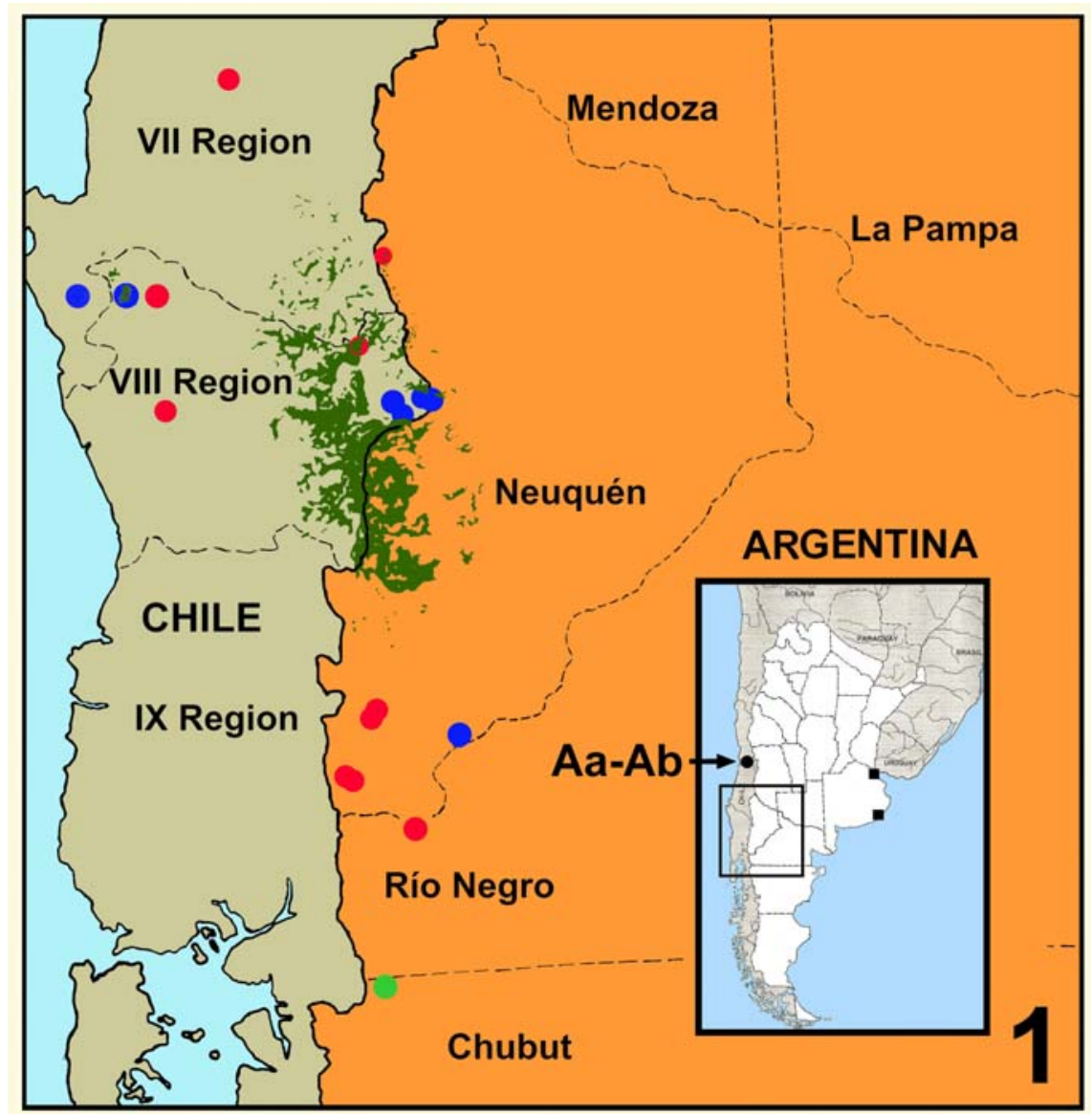

Fig. 1. Current distributions of Araucaria araucana (dark green areas, modified from Echeverría et al. 2004) and Huequenia livida: red circles, localities where $H$. livida were reared and/or observed on A. araucana (literature data and author's records); light green circle, locality where $H$. livida was recorded on Pinus contorta var. murrayana; blue circles, localities where specimens of $H$. livida were captured (examined from entomological collections and literature data); Aa-Ab, found on A. angustifolia and A. bidwilli (Chile: Santiago); black squares, transported specimens.

cages until new adults emerged (Supplementary file: Table S2). Emergences were recorded daily (Supplementary file: Tables S1, S2), with the numbers of specimens emerged in each date in parentheses. Each specimen (Supplementary file: Tables S1, S2) was labelled with locality and date of field collection of the host plant, and a smaller, second label with the host plant and emergence data. Plant names and abbreviations of authors are according to Wiersema \& León (1999).

Collections mentioned in literature (not examined)

BTCC, Barriga Tuñón Enrique collection, Curicó, Chile. CMCC, Cerda Miguel collection, Chile [currently MNHN]. EIIB, Ecología de Insectos, INTA Bariloche, Río Negro, Argentina.

MNHN, Museo Nacional de Historia Natural, Santiago, Chile.

MZSP, Museu de Zoologia, Universidade de São Paulo, São Paulo, Brazil.

PLSC, Peña Luis collection, Santiago, Chile [Cerambycidae currently in MZSP].

\section{Collections examined}

DIOC, Di Iorio Osvaldo collection, Buenos Aires, Argentina.
MPFA, Museo Provincial "Florentino Ameghino", Santa $\mathrm{Fe}$, Argentina.

SNSA, Servicio Nacional de Sanidad Animal, Buenos Aires, Argentina.

ZFNE, Zoología Forestal, Universidad Nacional del Comahue, San Martín de los Andes, Neuquén, Argentina.

\section{Results}

Subfamily Cerambycinae Latreille, 1804

Achrysonini Lacordaire, 1869

Huequenia araucana (Cerda, 1980)

See historic taxonomy and bibliographic references in Monné (2001: 10) except: Huequenia araucana: Martins 2002: 62 [key], 64 [distr.; re-descr.; refs.]

\section{Known geographic distribution}

CHILE: Malleco (Cerda 1986): Nahuelbuta National Park, 7-I-1966, M. Cerda leg., 1 male holotype [CMCC], 17 ex. paratypes [CMCC] (Cerda 1980; Martins 2002), 2 ex. paratypes [PLSC] (Cerda 1980); Nahuelbuta, II1953, L. Peña leg., 1 \& [DZUP], I-1966, M. Cerda leg., 2 ○๐ $^{\top}$ [DZUP], II-1968, M. Cerda leg., 1 \% [DZUP], I1976, M. Cerda leg., 2 ơ [DZUP], I-1978, M. Cerda leg., 3 ơ , 2 o९ [DZUP], XII-1983, M. Cerda leg., 1 
o [DZUP] (Martins 2002); Caramávida, 10-XI-1956, 3 ơ paratypes [PLSC] (Cerda 1980; Martins 2002); Llonquimay, Galletué, 3-I-1962, L. Peña leg., 2 ○’ paratypes [PLSC] (Cerda 1980; Martins 2002); Arauco: Pichinahuel (Cordillera de Nahuelbuta), I-1959, Dirings leg., 3 ơ $^{7}, 1$ ๆ [DZUP] (Martins 2002).

\section{Known host plants \\ Araucaria araucana}

CHILE: "it was found only in Araucaria araucana where it develops" [translated from Spanish] (Cerda 1980; Martins 2002); Malleco: Nahuelbuta National Park, $37^{\circ} 47^{\prime}$ S, $73^{\circ} 00^{\prime}$ W, 12-II-2005, J.E. Barriga leg., \# 169587, 1 ex. [BTCC], "fogging s/ Araucaria araucana" [printed label], "Huequenia / araucana / (Cerda, 1980) / det: JE Barriga" [printed label], extracted from http://www.coleoptera-neotropical.org/paginas/ 3_familias/CERAMBYCIDAE/chile/ Huequeniaaraucana.html (accessed 20.09.2012).

Remarks. According to Martins (2002), H. araucana can be characterized by the prothorax without lateral tubercles; the pronotum without smooth areas; the hairless vertex, scape pronotum and elytra; its smaller size (7.4-7.8 mm total length). In contrast, $H$. livida has lateral tubercles in the prothorax; pronotum with a small central area and two smooth gibbosities in front of its half length; the vertex, scape and pronotum finely pubescent; the elytra sparsely pubescent, and its greater size (10.2-13.2 mm total length).

\section{Huequenia livida (Germain, 1898)}

See historic taxonomy and bibliographic references in Monné (2001: 10-11) except: Huequenia livida (Germain, 1901): Turienzo 2005 [dist; host; ref.]: erratum pro livida Germain, 1901 [genus Sybila]

Huequenia livida (Germain, 1898): Martins 2002: 62-63 [distr.; hosts]; Turienzo 2006: 655-658 [biol.]; Villacide et al. 2006: 122-125 [distr.; hosts; refs.]; Pacini 2011: 17 [cat.; distr.]; Machado et al. 2012: 187 [host; ref.]

\section{Known geographic distribution (without host plant records)}

CHILE: Santiago: Santiago, without date, L. Peña leg., 1 ơ, 2 oๆ [MZSP], 18-X-1983, L. Vargas leg., 1 ơ [MZSP] (Martins 2002); Biobío: locality not stated (Cerda 1986; Martins 2002); Malleco: Galletué [= Laguna de Gualletue], II-1962, Valencia leg., 1 ○ [MZSP]; Icalma [= Paso de Icalma], 17-I-1962, L. Peña leg., 1 o [MZSP]; Licura (Lonquimay, $1800 \mathrm{~m}$ ), 6/10-I-1959, M. Cerda leg., 1 o', 1 \% [MZSP], I-1959, Dirings leg.,

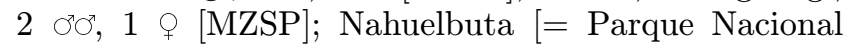
Nahuelbuta, $37^{\circ} 48^{\prime} 23^{\prime \prime}$ S, $\left.72^{\circ} 59^{\prime} 35^{\prime \prime} \mathrm{W}\right]$, XI-1936, Bullock leg., $3 \mathrm{O}^{\top} \mathrm{O}^{\top}$ [MZSP] (Martins 2002); Cabrería (1100 m) $\left[=\right.$ Estero Cabrería, $\left.37^{\circ} 49^{\prime} 35^{\prime \prime} \mathrm{S}, 73^{\circ} 00^{\prime} 49^{\prime \prime} \mathrm{W}\right]$, I1977, L. Peña leg., $1 \bigcirc^{\prime}[\mathrm{MZSP}]$; Pichinahuel [= Cerro Pichinahuel, $37^{\circ} 47^{\prime} 47^{\prime \prime}$ S, $\left.73^{\circ} 01^{\prime} 40^{\prime \prime} \mathrm{W}\right]$, 31-XII-1958, M. Cerda leg., 1 o [MZSP], I-1959, Dirings leg., 1 ○, 2 ㅇ [MZSP] (Martins 2002); Valdivia: locality not stated (Cerda 1986; Martins 2002).

\section{Known host plants}

Araucaria araucana

CHILE: uble: Agricultural School of Chillán, A. Besoaín leg., in dead trees of an avenue (Porter [1921] 1922a), = Chillán (Durán M. 1963, following Porter [1921] 1922a, 1922b); Malleco: Cordillera de Tolhuaca [type locality], 1 o', 1 \%, beating dry branches (Germain 1898; Cerda 1980), 2 syntypes [MNHN] (Martins 2002); Angol, 30-XI, D.S. Bullock leg., 3 ○ా [MZSP], labeled "en Araucaria imbricata" (Martins 2002); Cautín: Temuco, R.E. Baquedano leg., pupae inside pupal chambers (Porter [1921] 1922a 1922b), = "cordillera de Cautín" (Durán M. 1963, following Porter [1921] 1922a, b); (Duffy 1960, following Porter 1922a, dated 1923); (Cerda 1980); (Monné 2001); ARGENTINA: Neuquén: San Martín de los Andes, 10-I-2005, P. Turienzo \& O. Di Iorio leg, in basal dead branches on living trees (Turienzo 2005 2006).

\section{Araucaria angustifolia}

CHILE: Metropolitan Region: in dead wood (Barriga et al. 1993); (Martins 2002); Santiago, specimens in MNHN, on dead branches (Villacide et al. 2006); Talagante: Naltagua, I-1993, J.E. Barriga leg., \# 40213, 1 ex. [BTCC], "ex / Araucaria / angustifolia / (muerto)" [printed label], "Huequenia / livida / (Germain, 1898) / det: J.E. Barriga" [printed label], extracted from http://www.coleopteraneotropical.org/paginas/3familias / CERAMBYCIDAE /chile/Huequenia-livida. html (accessed 20-XI-2012).

\section{Araucaria bidwilli}

CHILE: Metropolitan Region: in dead wood (Barriga et al. 1993); (Martins 2002); Santiago, specimens in MNHN, on dead branches (Villacide et al. 2006).

Remarks. Barriga et al. (1993) mentioned that Huequenia araucana was reared from dead branches of cultivated plants of Araucaria angustifolia and A. bidwilli from the Metropolitan Region (= Santiago), later compiled by Monné (2001) and Martins (2002). Villacide et al. (2006) mentioned that the specimens deposited in MNHN with this origin and host plants belong to $H$. livida. Thus, there are two possibilities: 1) the identification made by Barriga et al. (1993) is correct, and both $H$. araucana and $H$. livida live in the same host plants in the Metropolitan Region, or 2) H. livida is the single species present in the Metropolitan Region, and the record of Barriga et al. (1993) is an error of identification of $H$. livida by $H$. araucana. Accordingly to the second possibility, specimens from Santiago were identified by Martins (2002) as belonging to $H$. livida, and one specimen from the Barriga collection (photo), collected near Santiago and reared from Araucaria angustifolia, proved to be $H$. livida. Therefore, both $A$. angustifolia and $A$. bidwilli originally recorded in the Metropolitan Region for $H$. araucana are in reality hosts of $H$. livida. 

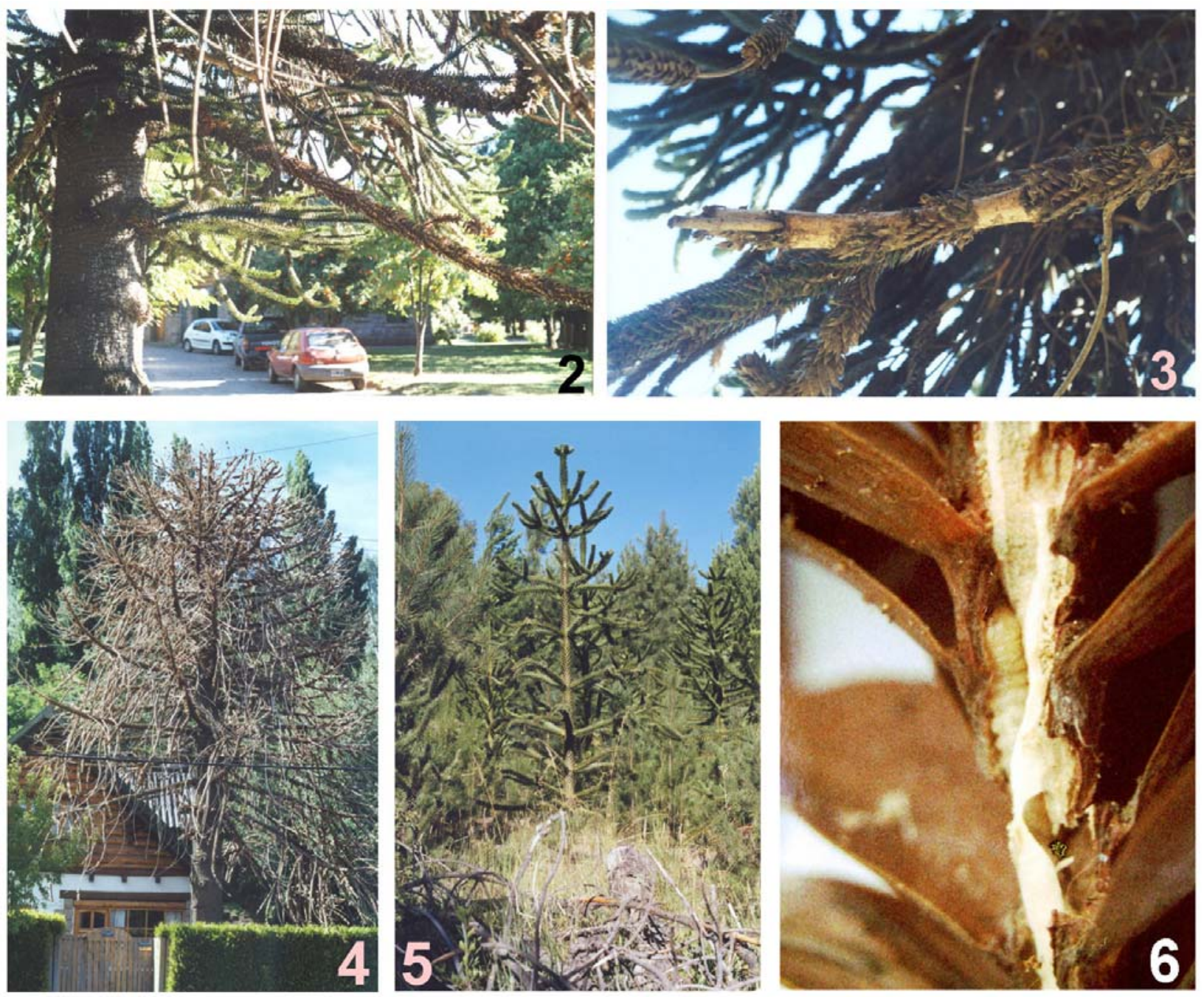

Figs 2-5. Habitats of Huequenia livida outside its natural geographic distribution. 2: Two recently dead basal branches of $A$. araucana infested with larvae in one cultivated tree at one square in San Martín de los Andes (Neuquén, Argentina); 3: Detail of a basal dead branch where remaining subcortical tissues and leaves has begun to fall to the ground (same place as Fig. 2); 4: Dead standing tree in the garden of a house at San Martín de los Andes, infested but not sampled; 5: Forestation of young trees of $A$. araucana mixed with Pinus contorta var. murrayana, where lopped branches of $A$. araucana (lower portion of the photo) were infested by $H$. livida (15 km NW of San Martín de los Andes).

Fig. 6. Larva of $H$. livida in a thin branch of $A$. araucana, feeding also inside the foliar bases.

Pinus contorta Douglas ex. Loudon var. murrayana (Balf.) Engelm

ARGENTINA: Chubut: Lago Puelo, summer 2005, previously infested by Sirex noctilio (F.) [Hymenoptera: Siricidae] (Villacide et al. 2005), [specimens not stated], in collections EIIB and MNHN (Villacide et al. 2006), summer 2005, J. Villacide leg., 13 ex. [MPFA] (Pacini 2011); [province and locality not stated], Argentinean Patagonia, found in "pino contorta", previously infested by Sirex noctilio (Gómez 2008); (Machado et al. 2012).

Remarks. Specimens examined in MPFA corresponding to this host do not bear host plant labels.

Pinus ponderosa Douglas ex Lawson \& C. Lawson

ARGENTINA: [province and locality not stated], Ar- gentinean Patagonia, found in "pino ponderosa", previously infested by Sirex noctilio (Gómez 2008).

\section{Pinus radiata D. Don.}

ARGENTINA: [province and locality not stated], Argentinean Patagonia, found in "pino radiata", previously infested by Sirex noctilio (Gómez 2008).

\section{New locality records of Huequenia livida}

Specimens examined (adults without host plant records). CHILE: Malleco: Pino Hachado, 6/10-I-1959, L.E. Peña leg., 1 ex. [DIOC]; ARGENTINA: Capital Federal: Puerto de Buenos Aires, "o / Chile / 4/ 6 / 03" [= origin Chile, printed label], 2 ex. [DIOC], 3 ex. [SNSA]; Neuquén: Pino Hachado, M. Gentili leg., 30-I-1974, 1 ex. [DIOC], 19-III-1974, 1 ex. [DIOC]; Dto. Los Lagos, Embalse Alicurá, 27-XI-2006, S. Tiranti leg., 1 ex. [ZFNE]. 
Remarks. The adults intercepted by the National Service of Animal Health were found in a container coming from Chile with "raulí \& pino Oregon wood" in the Buenos Aires port area. "Pino Oregon" is the common name used in the country for Pseudotsuga menziesii var. menziesii (Mirb.) Franco [Pinaceae]. This last plant was inspected in Villa La Angostura (Neuquén), but no infestations with $H$. livida were found.

\section{New localities and host plant records of Hueque- nia livida}

Specimens reared and larval tunnels and/or pupal chambers observed in the field

\section{Araucaria araucana}

ARGENTINA: South-western Argentina [unknown locality], 14-IX-1983, J. Farina leg., 1 ex. [DIOC], emerged in Mar del Plata from a feminine cone with one emergence hole in its base; Neuquén: San Martín de los Andes, 10-I-2005, P. Turienzo \& O. Di Iorio leg., 78 ex. [DIOC], first winter generation, 19 larvae and 2 pupae [DIOC], fixed 13-III-2005, 18 ex. [DIOC], summer generation, 17 ex. [DIOC], second winter generation (Supplementary file: Table S1), emerged from basal dead branches on one living tree; San Martín de los Andes, 17-I-2007, Turienzo \& Di Iorio leg., 36 ex. [DIOC], winter generation, 669 ex. [DIOC], summer generation (Supplementary file: Table S1), emerged from basal dead branches on one living tree (Figs 2, 3); $15 \mathrm{~km}$ north-eastern from San Martín de los Andes, 17-I-2007, Turienzo \& Di Iorio leg., 7 empty pupal chambers in lopped branches, 2 ex. [DIOC], winter generation (Supplementary file: Table S1), emerged from thin branches lopped from a young tree (Fig. 5); Villa la Angostura, I-2006, old larval tunnels and empty pupal chambers in basal dead branches on one living tree; Municipio de Villa Angostura, Puerto Manzano, 12/13-I-2007, Turienzo \& Di Iorio leg., 13 ex. [DIOC], winter generation, 2 ex. [DIOC], summer generation, emerged from basal dead branches on one living tree (Supplementary file: Table S1); Caviahue, 23-XI-2012, P. Turienzo (pers. obs.), larval tunnels and empty pupal chambers in basal dead branches on living trees; Río Negro: Bariloche, 13-VIII-2012, P. Turienzo (pers. obs.), old larval tunnels and empty pupal chambers in basal dead branches on one living tree.

Remarks. The specimen of Huequenia livida from Mar del Plata was found inside the Museo Municipal de Ciencias Naturales "Lorenzo Scaglia" (Mar del Plata, Buenos Aires province) some time after the donation of a feminine cone of Araucaria araucana from southwestern Argentina. One emergence hole in the cone stalk was observed.

\section{Araucaria angustifolia}

ARGENTINA: infested II-2005 in laboratory, 3 ex. [DIOC], winter generation, emerged from windfallen thin branches (Supplementary file: Table S2), infested II-2007, 38 ex. [DIOC], summer generation, emerged from a basal dead branch lopped from one living tree (Supplementary file: Table S2).

\section{Araucaria bidwillii}

ARGENTINA : infested II-2005 in laboratory, 8 ex. [DIOC], emerged from a basal dead branch lopped from one living tree (without emergence data).

\section{Pinus contortavar. murrayana}

ARGENTINA: infested II-2007 in laboratory, 38 ex. [DIOC], winter generation, emerged from a lopped dead tree $10 \mathrm{~cm}$ diameter (Supplementary file: Table S2).

\section{Biology of Huequenia livida}

In these dead branches, more than one successive stage can be seen. In the first, when the branch is recently dead, the larvae are feeding between the xylem and the subcortical tissues and leaves, but no emergence holes are seen (Fig. 2, ticker leafed branches). After two generations, and likely two more in the next year, parts of the subcortical tissues and leaves begin to fall (Fig. 3), and finally, the smooth wood of the branches remain on the plant (Fig. 2, thin branches). When larval density is very high, the dry tissues inside the leaf bases are also consumed, but the leaf cuticle remains intact (Fig. 6). The adults emerge by night, and they copulate immediately after emergences. Females oviposit immediately after copula, and they can re-infest the same branches from which they emerge.

\section{Generations per year and emergence periods}

Specimens of Cerambycidae originated in a summer generation are always scarce, and not detectable in a separate peak when compared with the high numbers of adults that passed the winter as larvae, emerging in spring and summer (October to January). These specimens that developed during summer are only detectable by the gap produced between the emergences of both winter and summer generations. The following species from Buenos Aires are good examples of this: Compsocerus violaceus (White, 1853), 561 ex. emerged between 16-IX-04 and 15-I-05, and 4 ex. emerged between 9-III-05 and 12-III-05; Paromoeocerus barbicornis (F. 1792), 20 ex. emerged between 6-X-02 and 17XII-02, and 5 ex. emerged between 21-I-03 and 27I-03; 50 ex. emerged between 16-IX-04 and 15-I-05, and 1 ex. emerged 5-III-05; 22 ex. emerged between 1-X-05 and 14-XII-05, and 2 ex. emerged between 9-I06 and 6-II-06; Neoclytus ypsilon Chevrolat, 1862, 189 ex. emerged between 21-X-03 and 9-II-04, and 6 ex. emerged between 1-III-04 and 5-IV-04 (Di Iorio unpublished data).

It can be observed from the emergence data (Tables $\mathrm{S} 1, \mathrm{~S} 2$ ) that $H$. livida has two generations per year. First, a winter generation, that overwinter as larvae and the corresponding adults emerge from October to February, and later, a shorter summer generation whose adults emerge from middle March to the beginning of June (Tables S1, S2). 


\section{Discussion}

Geographical distribution and dispersal of Huequenia livida

The Nothofagus forests of south-western Argentina were intensively prospected, and the insect fauna (especially Cerambycidae) was well known by great collectors in the western areas of Neuquén and Río Negro, i.e., Demetrio Havrylenko, Sergio Schajoskoy and Conrad Naumann Etienne. Nevertheless, H. livida was never reported from Argentina (Monrós [1943] 1944; Havrylenko \& Winterhalter 1949; Bosq 1953; Naumann Etienne circa 1973). Probably this was due that Araucaria araucana was not investigated in its original range (Fig. 1).

The more intensive study of the Araucaria forests in the Argentinean side was done by Rothkugel (1916), who also mapped the primitive extension of these forests. Among the diseases of some trees in the austral forests, no one stem borer was mentioned for $A$. araucana by Rothkugel (1916) when H. livida was already known from Chile (Germain 1898). The second wood borer in rotten wood of $A$. araucana was described by Bosq (1951) from Argentina and Chile [Acutandra araucana (Bosq, 1951)].

The oldest known specimen of $H$. livida found in Argentina dates from 1974 in a low pass of the Andean Mountains (Pino Hachado), where H. livida was also found in the Chilean side (Fig. 1) much before than in the Argentinean side. Pino Hachado and Caviahue are comprised in the natural distributión of $A$. araucana forests (Fig. 1).

The distribution of $H$. livida is comprised between parallels $35^{\circ}$ to $40^{\circ} \mathrm{S}$ in Chile (Martins 2002), but if this distribution is superimposed with the distribution of Araucaria araucana (Fig. 1), it can be seen that $H$. livida appears also outside the distribution of its host plant in both Chile and Argentina (Fig. 1). Therefore, it is possible to think that the presence of $H$. livida outside the natural distribution of $A$. araucana in Argentina and Chile may be the result of a recent dispersal following cultivated Araucaria trees (Figs 2-5). In Argentina, it can be also found in areas with forestations of Pinus spp. (Villacide et al. 2006). Noteworthy, it is coincident that Porter ([1921] 1922a) and Barriga et al. (1993) also report $H$. livida on cultivated trees of Araucaria, these last authors as far as the city of Santiago, Chile (Fig. 1, Aa-Ab).

This situation also occurs in Argentina with other native Cerambycidae species where their native host plants are cultivated out of its natural range (Di Iorio 1993, 1995), or with native Cerambycidae that had expanded their original distributions thanks to the adoption of new exotic larval hosts (Di Iorio 1998; Di Iorio \& Farina 2009).

Host plants of species in the genus Huequenia

The mention of Araucaria araucana as a native larval host plant of $H$. livida in Chile was done in few localities (Fig. 1). Germain (1898: 116) founds a male and a female of $H$. livida shook dry branches of $A$. araucana. Porter ([1921] 1922a) attributed to this beetle "dried a beautiful avenue of those trees" [translated from Spanish], and also mentions pupae in dry branches of the same host plant, as well as Porter (1922b). According to Peña (1960), H. livida "is other of the Cerambycidae species proper from the Araucaria Region; it is commonly found in fallen trees, and that had remained in this state by more than three months, being difficult that remains there if these trees are yet maintained by more than six months. It is frequent to found them in couples, because isolated I only saw them flying. I never collected this species with help of the light" [translated from Spanish].

No locality or other details were given by Peña (1960), but Martins (2002) cited only one specimen of H. araucana from Nahuelbuta as collected by Luis Peña prior to 1960 , while all specimens of $H$. livida were collected by Peña after 1960. Therefore, it will be necessary to examine all possible specimens collected by Peña for to know if Peña (1960) was speaking about $H$. livida or H. araucana. Also it is not clear if Cerda (1980) mentions previous records of $H$. livida on A. araucana (Germain 1898 is cited among the references), or if he also found and/or reared $H$. livida from this plant in one or in all localities, as well as for $H$. araucana.

The new observations made here does not agree with the observations of Porter ([1921] 1922a) because the death trees that he mentioned likely die by other factors, and not by Huequenia and then, H. livida appears developing on them. Barriga et al. (1993) also give $H$. livida as developing on dead wood in Chile (8a. Region). As this beetle develops in basal dead branches that naturally occur in living trees (Figs 2, 3) or in lopped branches (Fig. 5), it can't be considered of economic importance or an insect injurious to their host plants.

As the trees of $A$. araucana are cultivated out of its natural distribution, they may be exposed to some stress occasioned by the different environment. Therefore, it is not strange to observe some trees in gardens (Fig. 4) or public squares that die without apparent reason, which are after infested by $H$. livida.

The near phylogenetic relationship between $A$. $a$ raucana, $A$. angustifolia and $A$. bidwillii (Setoguchi et al. 1998) could explain the insect chosen of their hosts in laboratory. The actual distribution of these three species presents a barrier to the dispersion of this insect in their natural environment.

Villacide et al. (2006) record Pinus contorta var. murrayana (referred as "Pinus murrayana") from Chubut (Lago Puelo) as a host. Later, Gómez (2008) mentioned $H$. livida on three species of Pinus from the Argentinean Patagonia, but the province, locality, specimens emerged and repositories were not stated. According to Stefanovic et al. (1998), Pinaceae and Araucariaceae are not phylogenetically related. Nevertheless, the presence of H. livida in Pinus (Villacide et al. 2005, 2006) is confirmed here (Supplementary file: Table S2), a secondary likely recently adopted new host plant. 
All species of Pinus cited by Villacide et al. (2005 2006) and Gómez (2008) were previously infested by Sirex noctilio. This exotic wasp infests living plants that die by the inoculation of the fungus Amylostereum areolatum (Fr.) during the oviposition (Vizcarra Sánchez 2004). In contrast, H. livida infests dead and/or recently dead plants, making use of the available dead wood in the environment. The Pinus infested by $H$. livida in laboratory was not previously infested by $S$. noctilio, showing that this condition is not indispensable. Recent observations in Caviahue show emergence holes in $A$. araucana identical in size and shape to the emergence holes of Sirex noctilio in Pinus, showing that likelyS. noctilio was able to adopt a new host in the inverse way to $H$. livida. Further observations of this respect are urgently needed.

\section{Acknowledgements}

The authors are grateful to UBACYT, Proyect X 828 (to O. Di Iorio) for financial support of this study; Wolf Engels whose comments improved the manuscript in the first version; Norma Cardador \& Ricardo Fantini (Villa La Angostura), Andrea Medina \& Sergio Tiranti (San Martín de los Andes), Betty López \& Francisco Romero (Cavihaue) for the support in the respective places; Sergio Tiranti also for his field assistance; Parques Nacionales for allow us to take the dead branches in the Lanín National Park.

\section{References}

Barriga J.E., Curkovic T.S., Fichet T.L., Henriquez S.J.L \& Macaya B.J. 1993. Nuevos antecedentes de coleópteros xilófagos y plantas hospederas en Chile, con una recopilación de citas previas. Rev. Chil. Entomol. 20: 65-91.

Bosq J.M. 1951. Novedades en cerambícidos chilenos (Coleoptera Cerambycidae). Rev. Chil. Entomol. 1: 191-197.

Bosq J.M. 1953. Longicornios del Parque Nacional Lanín, zona de San Martín e los Andes y cercanía (Col. Cerambycidae), Anales del Museo Nahuel Huapí, Buenos Aires 3: 69-87, 5 pls.

Cerda M. 1980. Contribución al estudio de los cerambícidos de Chile (Coleoptera: Cerambycidae). Rev. Chil. Entomol. 10: 63-66.

Cerda M. 1986. Lista sistemática de los cerambícidos chilenos (Coleoptera: Cerambycidae). Rev. Chil. Entomol. 14: 29-39.

Di Iorio O.R. 1993. Asociación de Lochmaeocles sladeni (Gahan) (Coleoptera: Cerambycidae) con Enterolobium contortisiliquum (Vell.) Morong y Cathormion polyanthum (spreng.) Burk. (Leguminosae), y notas sobre otras Cerambycidae, depredadores y parasitoides [Association of Lochmaeocles sladeni (Gahan) (Coleoptera: Cerambycidae) with Enterolobium contortisiliquum (Vell.) Morong and Cathormion polyanthum (Spreng.) Burk. (Leguminosae), and notes on other Cerambycidae, predators and parasitoids]. Rev. Soc. Entomol. Argentina 52 (1-4): 63-71.

Di Iorio O.R. 1995. Lophopoeum timbouvae Lameere, 1884 and L. bruchi Monné \& Martins, 1976 (Coleoptera: Cerambycidae: Lamiinae: Acanthocinini): Their relation to fruits of Leguminosae. Giornale Italiano di Entomologia 7 (39): 231-245.

Di Iorio O.R. 1998. Torneutini (Coleoptera: Cerambycidae) of Argentina. Part 2. Biology of Coccoderus novempunctatus (Germar, 1824), Diploschema rotundicolle (Serville, 1834) and Praxithea derourei (Chabrillac, 1857). Giornale Italiano di Entomologia 9 (48): 3-25.

Di Iorio O.R. 2005. A Field Guide of the Longhorned Beetles (Coleoptera: Cerambycidae) from Argentina. Esteban Abadie
\& Pablo Wagner (Coordinators). Buenos Aires: P\&E Insects, 190 pp., 74 pls. ISBN: 9874394730

Di Iorio O.R. \& Farina J. 2009. Plantas hospedadoras de Cerambycidae (Coleoptera) de la provincia de Buenos Aires, Argentina. Revista del Museo Argentino de Ciencias Naturales "Bernardino Rivadavia" (N.S.) 11 (1): 77-99.

Duffy E. A. J. 1960. A Monograph of the Immature Stages of Neotropical Timber Beetles (Cerambycidae). British Museum of Natural History, London, 327 pp. ISBN-10:0565001094, ISBN-13: 978-0565001094

Durán M.L. 1963. Insectos de importancia económica para la Zona Austral. República de Chile, Ministerio de Agricultura, Dirección de Agricultura y Pesca, 71 pp.

Echeverría C., Zamorano C. \& Cortés M. 2004. Conservation and restoration of monkey puzzle (Araucaria araucana) forest in Chile. Final Report. May 2004, 17 pp. www.globaltrees.org./downloads/ChileReports.pdf (accessed 20.03.2005)

Ferrer M.S., Marvaldi A.E \& Tognelli M.F. 2007. First records of three species of Oxycraspedus Kuschel (Coleoptera: Belidae) in Argentina and use of a predictive model to compare their potential distribution with the range of their host-plant, Araucaria araucana. Rev. Chil. Hist. Nat. 80: 327-333.

Germain P. 1898. Apuntes entomolójicos. Los lonjicornios chilenos. 2.a Sub-familia: Los Cerambicidos. Anales de la Universidad de Chile 100: 541-562. DOI: 10.5354/0717-8883.1898. 21275

Gómez C.A. 2008. Principales especies de insectos forestales en plantaciones de Pino en la Patagonia, pp. 3-8. In: Villacide J. \& Corley J. (eds), Serie Técnica: Manejo Integrado de Plagas Forestales, Cambio Rural - Laboratorio de Ecología de Insectos, Instituto Nacional de Tecnología Agropecuaria EEA Bariloche, Cuadernillo (3), 10 pp. ISSN: 1851-4103

Havrylenko D. \& Winterhalter J.J. 1949. Insectos del Parque Nacional Nahuel Huapi. Ministerio de Obras Públicas de la Nación, Administración General de Parques Nacionales y Turismo, Buenos Aires, 53 pp.

Hawkeswood T.J. 1990. Observations on the biology, host plants and immature stages of Dihammus tincturatus Pascoe (Coleoptera: Cerambycidae: Lamiinae) in Papua New Guinea. Part 1. General biology and host plants. Giornale Italiano di Entomologia 5: 95-101.

Hawkeswood T.J. 1992. Review of the biology, host plants and immature stages of the Australian Cerambycidae (Coleoptera). Part 1. Parandrinae and Prioninae. Giornale Italiano di Entomologia 6: 207-224.

Hodge R.W. 1997. A new agonoxenine moth damaging Araucaria araucana needles in western Argentina and notes on the neotropical agonoxenine fauna (Lepidoptera: Gelechioidea: Elachistidae). Proc. Entomol. Soc. Wash. 99: 267-278.

Machado V.S., Botero J.P., Carelli A., Cupello M., Quintino H. \& Simőes M.V.P. 2012. Host plants of Cerambycidae and Vesperidae (Coleoptera, Chrysomeloidea) from South America. Revta Bras. Entomol. 56 (2): 186-198. DOI: 10.1590/S008556262012005000029

Martins U.R. 1965. Ibidionini (Coleoptera, Cerambycinae) XXIV. Divisão do gęnero Compsa Perty, 1832. Papéis Avulsos de Zoologia, Secretaria da Agricultura, São Paulo 17 (9): 89107.

Martins U.R. 2002. Tribo Achrysonini, pp. 37-144. In: Martins U.R. (ed.), Cerambycidae sul-americanos (Coleoptera), Taxonomia Vol. 4: Subfamilia Cerambycinae, Tribos Erlandiini Aurivillius, 1912, Smodicini Lacordaire, 1869, Achrysonini Lacordaire, 1869, Cerambycini Latreille, 1804 - Cerambycina Latreille, 1804, Sociedade Brasileira de Entomologia, São Paulo, 265 pp., 287 figs.

Mecke R. 2000. Two new species of cossonine weevils, Araucarius kuscheli spec. nov. and A. crassipunctatus spec. nov. (Coleoptera: Curculionidae) from southern Brazil. Studies on Neotropical Fauna and Environment 35 (3): 195-199. DOI: 10.1076/snfe.35.3.195.8860

Mecke R. 2004a. A new Brazilian bark beetle, Xylechinosomus lucianae sp. n. (Coleoptera, Curculionidae, Scolytinae, 
Tomicini), from Araucaria angustifolia (Coniferae, Araucariaceae). Dtsch. Entomol. Zeitschr. 51 (2): 217-220. DOI: 10.1002/mmnd.20040510204

Mecke R. 2004b. New species of Pachycotes Sharp and Xylechinus Chapuis (Coleoptera: Curculionidae: Scolytinae, Tomicini) from New Caledonian Araucaria spp. (Coniferales: Araucariaceae). N. Z. J. Zool. 31 (4): 343-349. DOI: 10.1080/0301 4223.2004.9518387

Mecke R. \& Galileo M.H.M. 2004. A review of the weevil fauna (Coleoptera, Curculionoidea) of Araucaria angustifolia (Bert.) O. Kuntze (Araucariaceae) in South Brazil. Revta Bras. Zool. 21 (3): 505-513. DOI: 10.1590/S010181752004000300013

Mecke R., Galileo M.H.M \& Engels W. 2000a. Insetos e ácaros associados à Araucaria angustifolia (Araucariaceae, Coniferae) no sul do Brasil [Insects and mites associated with Araucaria angustifolia (Aracauriaceae, Coniferae) in southern Brazil]. Iheringia, Sèrie Zoologia, Porto Alegre 88: 165-172.

Mecke R., Galileo M.H.M. \& Engels W. 2001. New records of insects associated with Araucaria Trees. Phytophagous Coleoptera and Hymenoptera and their Natural Enemies. Studies on Neotropical Fauna and Environment 36 (2): 113-124. DOI: $10.1076 /$ snfe.36.2.113.2132

Mecke R., Silva Barbosa M. \& Engels W. 2000b. A new Brazilian Sawfly, Derecyrta araucariae spec. nov. (Hymenoptera: Xiphydriidae), associated with Araucaria angustifolia (Bert.) O. Kuntze. J. Kansas Entomol. Soc. 73 (3): 177-182.

Monné M.A. 2001. Catalogue of the Neotropical Cerambycidae (Coleoptera) with known host plant - Part I: Subfamily Cerambycinae, tribes Achrysonini to Elaphidiini. Publicaçoes avulsas do Museu Nacional, Rio de Janeiro 88: 1-108.

Monrós F. [1943] 1944. Algunos coleópteros de interés forestal observados en la Isla Victoria (Gobernación de Neuquén). Revista de la Facultad de Agronomia y Veterinaria, Universidad de Buenos Aires 10 (3): 1-10, 2 figs.

Naumann Etienne C. 1973. Contribución al conocimiento sistemático y ecológico de la entomofauna de los bosques de Nothofagus en elParque Nacional Nahuel Huapi. Tesis del doctorado en Ciencias Biológicas. Universidad Nacional de Córdoba, Córdoba, 131 pp.

Pacini A. 2011. Catálogo de escarabajos de cuernos largos (Coleoptera: Cerambycidae) de la colección de invertebrados del Museo Provincial de Ciencias Naturales "Florentino Ameghino". Museo Provincial de Ciencias Naturales "Florentino Ameghino", Serie N²6, 41 pp.
Pastrana J.A. 1950. Una nueva peste en Araucarias de Misiones (República Argentina). Revta Investig. Agricol. 4 (2): 243246.

Peña L.E. 1960. Algunas observaciones poco conocidas de Cerambycidae (Insecta - Coleoptera) de Chile. Revta Univ. Catól. Santiago 44-45: 57-61.

Porter C.E. [1921] 1922a. Notas breves sobre longicornios chilenos. 2. Un insecto que ataca a la Araucaria. Revta Chil. Hist. Natur. Santiago 25: 497-498.

Porter C.E. 1922b. Un longicornio nocivo a la Araucaria. Anls. Zool. Aplic., Santiago 9: 38.

Rothkugel M. 1916. Los bosques patagónicos. Ministerio de Agricultura, Dirección General de Agricultura y Defensa Agrícola, Oficina de Bosques y Yerbales, Buenos Aires, 204 pp.

Setoguchi H., Osawa T.A., Pintaud J.C., Jaffré T. \& Veillon J.M. 1998. Phylogenetic relationships within Araucariaceae based on RBCL gene sequences. Am. J. Bot. 85 (11): 1507-1516. PMID: 21680310

Stefanovic S., Jagel M., Deutsch J., Broutin J. \& Masselot M. 1998. Phylogenetic relationships of conifers inferred from partial 28s rRNA gene sequences. Am. J. Bot. 85 (5): 688-697. PMID: 21684951

Turienzo P. 2005. Nuevo registro de Huequenia livida (Germain, 1901) (Coleoptera: Cerambycidae) en Araucaria araucana (Mol.) Koch (Araucariaceae) de la Argentina. Boletín de Sanidad Vegetal, Plagas 31 (4): 517-518.

Turienzo P. 2006. Larval galleries and pupal chambers of Huequenia livida (Germain, 1898) (Coleoptera: Cerambycidae). Boletín de Sanidad Vegetal, Plagas 32 (4, 2): 655-658.

Villacide J.M., Sackmann P. \& Elgueta M. 2005. Primer registro del "Taladro del Pehuén" Huequenia livida (Germain) (Coleoptera: Cerambycidae) para Argentina, p. 125. In: Resúmenes, VI Congreso Argentino de Entomología. San Miguel de Tucumán, 12 al 15 de Septiembre de 2005, Sociedad Entomológia Argentina.

Villacide J.M., Sackmann P. \& Elgueta M. 2006. Nuevo hospedador de Huequenia livida (Coleoptera: Cerambycidae) en Argentina. Revta Soc. Entomol. Argentina 65 (1-2): 122-125.

Vizcarra Sánchez J. 2004. Plagas y enfermedades forestales de Misiones. Editorial Universitaria de Misiones, Posadas, 224 pp. ISBN: 9505790120, 9789505790128

Wiersema J.H. \& León B. 1999. World Economic Plants. A Standard Reference. CRC Press. Boca Raton, London, New York \& Washington D.C., 792 pp. ISBN-10: 0849321190, ISBN-13: 978-0849321191 